Behavior and Social Issues, 26, 4 (2017). (C Behaviorists for Social Responsibility. Readers of this article may copy it without the copyright owner's permission, if the author and publisher are acknowledged in the copy and the copy is used for educational, not-for-profit purposes. doi: 10.5210/bsi.v.26i0.8239

\title{
CALl FOR PAPERS BEHAVIORAL ACTIVISM AND ADVOCACY
}

As a part of Behaviorists for Social Responsibility's Matrix Project (see www.bfsr.org) we are soliciting examples of activism and advocacy work discussed from a behavior analytic or behavioral systems framework. Such examples may include efforts by behavior analysts, or descriptions of efforts with which behavior analysts are familiar, and which they can discuss from a behavioral perspective. Submissions of 300-2000 words will be considered for publication in a special, on-going section, "Activism and Advocacy Notes," of Behavior and Social Issues; longer submissions will be reviewed as regular articles for the journal. (Notes will receive expedited review.) All submissions should be in strict APA format, meet scientific standards, and be congruent with the BFSR mission of supporting social justice, human rights, and sustainability and environmental justice.

Examples of possible submissions might include an analysis of the activities of a refugee or sanctuary project, an advocacy campaign focused on a state legislature, a sustainability project within a local community, local organizing to meet the needs of homeless persons, or a national group working to protect public lands and waters. Submissions should either conceptually or (occasionally) experimentally explore effective or ineffective efforts to shift patterns of interlocking contingencies, metaand macrocontingencies, or behavioral systems dynamics involved in the focal advocacy effort. Where possible, it would be of value to include attention to related literature (for example, literature on effective legislative lobbying), but this attention need not be encyclopedic. The purpose of this project is to expand examples of behavioral systems advocacy from which students and other behavior analysts can benefit in their own activist work.

We are especially interested in submissions by students of behavior analysis, and encourage related individual or group assignments (required or optional) within behavior analysis education programs that encourage activism while offering new publication opportunities for students. We also particularly welcome submissions from behavior analysis teaching faculty, behavior analysts in practice, and senior scholars with commitment to the social justice, human rights, and environmental mission of BFSR. 